\title{
Identifying Social Commerce Features towards Improving a Social Commerce Website
}

\author{
Norshaharizan Puteh', JamilahDin², Salmi Baharom³ ${ }^{3}$, Delaila Abdullah ${ }^{4}$ \\ ${ }^{1}$ Universiti Kuala Lumpur, MIIT, Kuala Lumpur, Malaysia \\ ${ }^{2,3}$ Universiti Putra Malaysia, Selangor, Malaysia \\ ${ }^{4}$ Universiti Kebangsaan Malaysia, Selangor, Malaysia \\ norshaharizan@unikl.edu.my ${ }^{1}$, jamilahd@upm.edu.my²,salmi@upm.edu.my ${ }^{3}$,delaila75@yahoo.com
}

Article History: Received: 10 November 2020; Revised: 12 January 2021; Accepted: 27 January 2021; Published online: 05 April 2021

\begin{abstract}
Social commerce has become more popular compared to e-commerce. This is caused by the transition development of the business transaction website. It has shifted from the e-commerce website towards the social commerce website. The e-commerce website has its standard features. However, there are few features in the market for the social commerce website. This research focuses on investigating the essential functions of social commerce that should be embedded into the social commerce website. The process of identifying social commerce features is done through literature reviewand summarized the features. The summarized characteristics than are analyzed and discussed with three expert reviewers to conform to the relevant social commerce features. At this phase, it involves several steps where the discussion started with an individual interview. The outcome then is consolidated into a table. The reviewed then be emailed to expert reviewers to get their feedback. The agreement from all of them then be gathered and summarized in a new set of features. The outcome of thisstudy will be useful for the development of a design template for a social commerce website.
\end{abstract}

Keywords:e-commerce website, social commerce website, social commerce features

\section{Introduction}

The twenty-first century has seen digital evolution with Web 2.0's emergence that has uniquely changed the method of how a business is run, moving away from only using a brick-and-mortar setting to creating a complex web of platforms (Lin et al. 2017).

Consequently, another term has derived, which is calledsocial commerce. Social commerce is a subset of electronic business that involves social media. It refers to online media that supports social interaction and user contributions. It is to assist a few areas such as online buying and the act of selling and also services.

In short, social commerce is referring to the use of a social network(s) in the context of e-commerce transactions. Social business is very much applicable through various social networks or social media platforms. It started with several applications such as Myspace, Second Life and Friendster. It is followed by representing personal or professional networks which can be seen as portrayed in Facebook and LinkedIn, followed by some other heavily visual platforms such as Pinterest, Instagram and lastly, the generating viral post in seconds for example, on Twitter. (Garraham 2009; Linkedln 2015; Smith 2015).

Based on previous references as mentioned by Busalim \& Hussin(2016), the examples of social commerce features are rating and review, recommendation and online forum. In another text by (Cheng, Gu, Shen, 2019), they highlighted the rating, review and recommendation features in social commerce. Whereas Ismail, Dahlan \& Hussin (2017) identified several features such as Promote and Attracted Others, Create Self-Identity and Sense of Community, Generate Content and Act Collectively, in which each suitable social commerce feature will fall under these categories.

However, these features have not to go through any validation processes and a series of testing. The procedures are vital to determine that the elements are needed in the social commerce website. Hence, references for social commerce features need to be further discussed and investigated in the future.

In general, this study contributes to the existing research by consolidating all the relevant and current values in the market about social commerce features and applythem to one social commerce website. It serves as a reference to novice enterprise developers to take a look and be aware of whatsocial commerce features should be asrequisites in completing an existing e-commerce website.

The remainder of this paper is organized as follows:the literature review section will highlight on the previous researches about social commerce features. The study continues with the steps to process data analysis. It will then continue with the results and discussions after the data analysis process has been done. Finally, the paper concludes with the conclusion on the finding of the study and recommendation for future reference. 


\section{Literature Review}

According to Huang \&Benyoucef(2015), social commerce can be defined as "An Internet-based commercial application, combination of social media and Web 2.0 technologies which support social interaction and usergenerated content to assist consumers in their decision power and purchase of products and services within online marketplace and communities". On the other hand, the social commerce term is built up by three main concepts, namely the social media, Web 2.0 technologies and e-commerce (Busalim\&Hussin, 2016).

Social commerce has some unique characteristics compared with traditional e-commerce (Busalim\&Husssin, 2016) and (Hussain \& Subramaniam, 2020). Based on the system interaction, social business has been widely considered as a context where user-generated content can be created, shared and thus, affect other members; in which their purchase intentions can be influenced,while the traditional e-commerce only provides one-way browsing, and the creation of content is mainly dominated by platform operators and customers usually receive information passively (P. Maragathavalli, et al, 2020).

However, e-commerce pays more attention to the presentation of products and services and optimization of search engine and navigation. Thus, the social commerce environment shifts online marketplace from productoriented platforms to the customer-oriented environment (Busalim\&Hussin, 2016).

Social commerce is classified into three primary trends: adding commercial features to social media tools (e.g. SNSs), adding social media features to e-commerce sites (e.g. Amazon), and the increasing use of social media by traditional offline firms to improve business performance (e.g. customer service) (Liang et al., 2011, $\mathrm{Ng}, 2013$ and Hussain et al., 2016). Social media is the platform where social commerce activities occur, and focuses on users' online collaborative shopping via information sharing, with an emphasis on improving WOM and brand loyalty (Wang \& Zhang, 2012).

From several references on academic papers, researchers have found the social commerce features as summarized in Table1. These features are taken from fifteen papers. From the tabulation, there is no specific pattern found but all the papers mostly cover only three elements. 'Review'is the highest number of feature covered by the documents with a total of fourteen articles, followed by rating with ten papers and the third highest is recommendation covered by nine papers. The other features are 'online forum'which was mentioned by seven papers andother features that were mentioned either three times, twice or once respectively. Table 1 below shows the distribution of social commerce features from fifteen articles.

To get the most comprehensive and latest information about the requirements, there are two processes involved. First, as summarized in Table 1 above, there is current information related to the domain area through the process of literature reviews. Next, this information is validated by three expert reviewers of the social commerce domain expert who are made up of social commerce freelance developers. The process of analyzing data will be explained more in the next section.

\section{Data Analysis}

In this phase, there were several meeting sessions involved with three expert reviewers. These reviewers were social commerce domain experts. Two of them are seniors in these fields and had various experiences in developing several systems for more than nine years such as web development, e-commerce web development, social commerce web development, mobile application development and others. Another reviewer is quite young and is gaining experience in the same field. The twenty social commerce features found in Table 1 above have been brought forward and discussed with them. The process of data analysis involved several steps, as described below. The first three meeting sessions have been set up with the three expert reviewers to evaluate the identified social features.

A discussion was held to identify which social commerce features were relevant to be classified and suitable to be used among the novice level. The argument elaborated on the prepared template, which allows them to choose the social commerce features and ticked accordingly. Before they confirmed with their selection, there were serious discussions and arguments before determining their range. 
Table 1.Distribution of social commerce features from papers

\begin{tabular}{|c|c|c|c|c|c|c|c|c|c|c|c|c|c|c|c|c|c|c|c|c|}
\hline Author $(s)$ & 1 & 2 & 3 & 4 & 5 & 6 & 7 & 8 & 9) & 10 & 11 & 12 & 13 & 14 & 15 & 16 & 17 & 18 & 19 & 21 \\
\hline $\begin{array}{l}\text { (Boardman, Blazquez, } \\
\text { Henninger, \& Ryding, 2019) } \\
\text { Chapter 1 }\end{array}$ & & & $\checkmark$ & l & & & & & & & & & & & & & & & & \\
\hline $\begin{array}{l}\text { BBardman, Blazquer, } \\
\text { Henminger, \& Ryding, 2019) } \\
\text { Chapter2 2 } \\
\end{array}$ & & & & & & & & & & & & $\sqrt{ }$ & i & & & & & & & \\
\hline $\begin{array}{l}\text { (Boardman, Blazquez, } \\
\text { Henninger, \& Ryding, 2019) } \\
\text { Chapter 14 } \\
\end{array}$ & & & v & & & & & & & & & & $\sqrt{ }$ & & & & & & & \\
\hline (Busalim \& Hussin, 2016) & & V & $\sqrt{ }$ & V & V & & & & & & & & & & & & & & & \\
\hline (Cheng, Gu, \&Shen, 2019) & & V & $\sqrt{ }$ & V & & & & & & & & & & & & & & & & \\
\hline \begin{tabular}{|l} 
Hajili, Wang, Tajiditi, \\
\& Hajili,2017) \\
\end{tabular} & & l & $\sqrt{ }$ & v & V & & & & & & & & & & & & & & & \\
\hline (Han \& Trimi, 2017) & & V & । & V & V & & & V & & & & & & V & & & & & & \\
\hline$(\mathrm{Han}, \mathrm{Xu}, \&$ Chen, 2018) & & & $\checkmark$ & & & & & & & & & & & & & & & & & \\
\hline $\begin{array}{l}\text { Huang \& Benyoucef, } \\
2015)\end{array}$ & & l & l & v & & l & l & & & & & & & & & & & & & \\
\hline $\begin{array}{l}\text { (Imail, Dahlan, } \\
\text { \& Hussin,2017) }\end{array}$ & & l & l & & & & l & & & & & & & & & & & & & \\
\hline (i,2019) & & 1 & 1 & 1 & V & & & i & 1 & 1 & 1 & & & & & & & & & \\
\hline (Lin, Li, \& Wang, 2017) & & V & I & & V & & & & l & l & & & V & V & & & & & & V \\
\hline $\begin{array}{l}\text { Pratama, Meivanti, Noprisson, } \\
\text { Ramadhan, } \\
\text { \& Hidayanto, 2018) } \\
\end{array}$ & $\sqrt{ }$ & l & v & l & l & & & & & & & & & & & & & & & \\
\hline \begin{tabular}{|l}
$($ Salatatori \& Marrantoni, \\
2015) \\
\end{tabular} & & $\checkmark$ & $\checkmark$ & l & l & & & l & & & & & & & v & $\downarrow$ & v & l & v & \\
\hline (Yan et tal, 2016) & & & $\checkmark$ & & & & & & & l & & & & & & & & & & \\
\hline
\end{tabular}

\begin{tabular}{|c|c|c|c|}
\hline 1 & Searching (1) & 11 & Ranking Toos(1) \\
\hline 2 & Rating 10$)$ & 12 & Like(1) \\
\hline 3 & Reviver(14) & 13 & Share(3) \\
\hline 4 & Recommendation(9) & 14 & Electronic Word of Mouth(2) \\
\hline 5 & Oonline Fornm(7) & 15 & Gitit Shipment(1) \\
\hline 6 & Feedbaak Mechanism(1) & 16 & Group Buying(1) \\
\hline 7 & Product Customization(2) & 17 & Chat Rooms(1) \\
\hline 8 & Wish Lis(3) & 18 & Newsletter(I) \\
\hline 9 & Videos(2) & 19 & Interaction with 3D models of items(1) \\
\hline 10 & Blog(3) & 20 & Pictures(1) \\
\hline
\end{tabular}

The secondprocess continued with the collection of their feedback with the identified social commerce features based on their selection from the template. The outcome from the series of discussion was to reanalyze and come up with a new set of social commerce features.

Next, with the new set of social commerce features in place, the process continued with the resubmissionof the revised template to the reviewers for re-evaluation. This process was done through email, just to get their agreement for the release of the new set.

Finally, upon agreement with all the three reviewers, the set of social commerce features was updated. Feedback from the discussion and the outcome of the social commerce features are available to in the next section.

\section{Result and Discussion}

Table 2 below shows the summary report based on the feedback after meeting with all the reviewers. Reviewer 1 has chosen fifteen of the social commerce features, reviewer two has chosen sixteen social commerce features, while the third reviewer has elected only three social commerce features. Generally, these 
two reviewers have similarity in their selected features due to the fact ofthe current trendswhich focusing onnovice entrepreneurs. They focus on the template with suitable characteristics for standard template pagesyet not for the custom template pages.There is a reason why the third reviewer sticks with only three social commerce features. He stresses that the website should stand as an e-commerce platform with these three standard features only. However, the rest of the social commerce features can stand on the platform itself, such as blogs, like share, etc. All of these social commerce features connecting and contribute directly to one another.

Table 2.The summarization of reviewers' selection

\begin{tabular}{|l|l|l|l|l|}
\hline No. & Social Commerce Features & Reviewer 1 & Reviewer 2 & Reviewer 3 \\
\hline 1. & Searching & $\sqrt{ }$ & $\sqrt{ }$ & \\
\hline 2. & Ratings & $\sqrt{ }$ & $\sqrt{ }$ & \\
\hline 3. & Reviews & $\sqrt{ }$ & $\sqrt{ }$ & $\sqrt{ }$ \\
\hline 4. & Recommendations & $\sqrt{ }$ & $\sqrt{ }$ & $\sqrt{ }$ \\
\hline 5. & Online Forums & $\sqrt{ }$ & $\sqrt{ }$ & \\
\hline 6. & Feedback Mechanisms & $\sqrt{ }$ & $\sqrt{ }$ & \\
\hline 7. & Product Customization & & $\sqrt{ }$ & \\
\hline 8. & Wish Lists & $\sqrt{ }$ & \\
\hline 9. & Videos & $\sqrt{ }$ & \\
\hline 10. & Blogs & $\sqrt{ }$ & $\sqrt{ }$ & \\
\hline 11. & Ranking Tools & $\sqrt{ }$ & $\sqrt{ }$ & \\
\hline 12. & Likes & $\sqrt{ }$ & $\sqrt{ }$ & \\
\hline 13. & Shares & $\sqrt{ }$ & $\sqrt{ }$ & \\
\hline 14. & Electronic Word of Mouths & & & \\
\hline 15. & Gift Shipments & & & \\
\hline 16. & Group Buying & & $\sqrt{ }$ & \\
\hline 17. & Chat Rooms & $\sqrt{ }$ & $\sqrt{ }$ & \\
\hline 18. & Newsletters & & & \\
\hline 19. & Interaction with 3D models of & & $\sqrt{ }$ & \\
\hline 20. & Pictures & $\sqrt{ }$ & \\
\hline
\end{tabular}

Based on the mapping shown from Table 2 above, the selection reviews given by the two (2) reviewers have a more extensive selection of coverage on the social commerce features that has been pointed out in developing the suitable references for new enterprise developer (novice). Therefore, the total social commerce features are 15 only, as shown in Table 3 below.

Table 3.The finalized social commerce features

\begin{tabular}{|l|l|c|}
\hline No. & Social Commerce Features & Apply \\
\hline 1. & Searching & $\sqrt{ }$ \\
\hline 2. & Rating & $\sqrt{ }$ \\
\hline 3. & Review & $\sqrt{ }$ \\
\hline 4. & Recommendation & $\sqrt{ }$ \\
\hline 5. & Online Forum & $\sqrt{ }$ \\
\hline 6. & Feedback Mechanisms & $\sqrt{ }$ \\
\hline 7. & Wish List & $\sqrt{ }$ \\
\hline 8. & Videos & $\sqrt{ }$ \\
\hline 9. & Blogs & $\sqrt{ }$ \\
\hline 10. & Ranking Tools & $\sqrt{ }$ \\
\hline 11. & Like & $\sqrt{ }$ \\
\hline 12. & Share & $\sqrt{ }$ \\
\hline 13. & Chat Rooms & $\sqrt{ }$ \\
\hline 14. & Newsletter & \\
\hline 15. & Pictures & \\
\hline
\end{tabular}




\section{Conclusion}

Based on previous papers that we have studied, most social commerce features mentioned are scattered all around - no one article said about all the social commerce features in one reference. Therefore, we have to gather from several Thipapers to compile the subject matter in this research.

The achievement is that all the scattered social commerce features found will enable the researchers to collect the data and put everything in one place and later develop it. This achievement is to show to the community especially to the novice entrepreneurs, that is the extension of Web 2.0, the world is not only depending on ecommerce, but the most significant is its integration with the social commerce features. Thus, it enables the platforms to link with the community and get convincingrecommendations and sharing of ideas. Thissocial behaviour will benefit both parties in terms of the indirect promotion ofproducts and boostingsales on the part of the sellers.

Asfor the recommendations of future research, we propose that the prospective study should focus on the development of the third reviewer's idea based on his knowledge and experience. Hesuggested that the development of the website should stand as e-commerce with standard features of social commerce like rate, review and rating. However, the application of the social business on other features will be on its platforms, such as blogs, Facebook groups, etc. All of these are inter-connected, and they contribute directly to one and another.

\section{References}

1. Busalim, A. H., \& Hussin, A. R. C. (2016). Understanding social commerce: A systematic literature review and directions for further research. International Journal of Information Management, 36(6), 1075-1088.

2. Cheng, X., Gu, Y., \& Shen, J. (2019). An integrated view of particularized trust in social commerce: An empirical investigation. International Journal of Information Management, 45(August 2018), 1-12.

3. Garrahan, M. (2009). The rise and fall of MySpace. Financial Times (online). Retrieved https://www.ft.com/content/fd9ffd9c-dee5-11de-adff-00144feab49a.16 June 2018.

4. Huang, Z., \& Benyoucef, M. (2015). User preferences of social features on social commerce websites: An empirical study. Technological Forecasting and Social Change, 95, 57-72.

5. Hussain, A., Subramanian, G. (2020). A bibliometric research analysis for online booking. Journal of Advanced Research in Dynamical and Control Systems, 12 (6), pp. 1671-1679.

6. Hussain, A., Mkpojiogu, E.O.C., Yusof, M.M. (2016). Perceived usefulness, perceived ease of use, and perceived enjoyment as drivers for the user acceptance of interactive mobile maps. AIP Conference Proceedings, 1761, art. no. 020051.

7. Ismail, N. B., Dahlan, H. M., \& Hussin, A. R. C. (2017). Technical features for social commerce website. 6th ICT International Student Project Conference: Elevating Community Through ICT, ICTISPC 2017, 2017-Janua, 1-5.

8. Liang, T.-P., \& Turban, E. (2011). Introduction to the special issue of social commerce: A research framework for social business. International Journal of Electronic Commerce, 16(2), 5-14.

9. Lin, X., Li, Y., \& Wang, X. (2017). Social commerce research: Definition, research themes and the trends. International Journal of Information Management, 37(3), 190-201.

10. LinkedIn. (2015). History of LinkedIn. LinkedIn (online). Retrieved https://ourstory. linkedin.com/. 16 June 2018.

11. Ng, C. S.-P. (2013). Intention to purchase on social commerce websites across cultures: A crossregional study. Information \& Management, 50, 609-620.

12. P. Maragathavalli, M. Seshankkumar, V. Dhivakaran \& S. Ravindran. (2020). Enhancing Security using MD5 and SHA-1 in TLS for Web application. IIRJET. V-5, I-3.

13. Smith, C. L. (2015). Ellen DeGeneres' Oscars selfie beats Obama retweet record on Twitter. The Guardian (online). Retrieved https://www.theguardian.com/film/2014/mar/03/ellen-degeneres-selfieretweet-obama. 16 June 2018.

14. Wang, C., \& Zhang, P. (2012). The evolution of social commerce: The people,management, technology, and information dimensions. Communications ofthe Association for Information Systems, $31,105-127$. 